\title{
Serdülők étkezési szokásai az „egészséghit-modell”, illetve az énhatékonyság, az optimizmus és az önkontroll tükrében
}

\author{
Adolescents' dietary habits in light of the Health Belief Model, self-efficacy, \\ optimism and self-control
}

Szerzők: $\quad$ Szabó Katalin ${ }^{\mathrm{a}}$, Pikó Bettina ${ }^{\mathrm{b}} \bowtie$

a: SZTE Neveléstudományi Doktori Iskola, Szeged, PhD hallgató,

b: SZTE Magatartástudományi Intézet, Szeged, egyetemi tanár

Beküldve: $\quad$ 2019. 07. 03.

doi: $\quad$ 10.24365/ef.v60i6.497

\begin{abstract}
Összefoglaló:
Bevezetés: Manapság egészségünk fenntartása és a betegségek megelőzése központi társadalmi célkitűzés. Különböző viselkedési modellek segítségével számos kutatás irányul arra, hogy feltérképezze az egészséges és az egészségtelen életmód szempontjait. Ezek közül kiemelten fontos a táplálkozás, mivel az egészségtelen étkezési szokásokból eredő betegségek és elhízás nemcsak hazánkban, hanem világszerte is súlyos népegészségügyi probléma. A megfelelő táplálkozási szokások kialakítása szempontjából a serdülőkor különösen érzékeny időszak a végbemenő testi és lelki változások miatt. Ezért kutatásunk központi eleme középiskolások tudatos ételválasztási preferenciáira ható tényezők felmérése. Célkitúzésünkhöz az „egészséghit-modell” elemeit vettük alapul, amelyeket kiegészítettünk bizonyos személyiségbeli jellemzőkkel (énhatékonyság, optimizmus, önkontroll), hogy feltárjuk a tudatos étkezéssel való összefüggéseiket.
\end{abstract}

Módszertan: Vizsgálatunkat szegedi középiskolákban végeztük 440 fö bevonásával. A minta 37\%-a fiú volt, életkoruk átlaga 16,0 év, szórása 1,2 év volt. Az adatgyüjtéshez online önkitöltős kérdőívet alkalmaztunk. Statisztikai elemzésünk során korreláció- és regresszióanalízist használtunk.

Eredmények: Adataink a vizsgált serdülők körében az „egészséghit-modell” elemei, a személyiségbeli tényezők és a tudatos étkezés között számos kapcsolatot állapítottak meg. A regreszszióelemzés eredménye szerint a tudatos étkezést legnagyobb mértékben az egészséges étkezés fontossága, a viselkedésváltozásból következő haszon, az önkontroll, valamint kisebb mértékben az énhatékonyság segíti elő, míg az észlelt korlátok változója gátolja. A fiúknál szignifikáns jósló erővel rendelkezett a táplálkozással összefüggő betegségekre vonatkozó észlelt hajlam, valamint az énhatékonyság, míg a lányoknál ezek a változók nem szerepeltek prediktorként. Mindkét nemnél az egészséges ételek fogyasztásának fontossága volt a legerősebb tényező.

Következtetések: Eredményeinkből arra következtethetünk, hogy az „egészséghit-modell”, kibővítve egyéb releváns pszichológiai változókkal, felhasználható elméleti háttérként serdülők étkezési szokásainak megismerésére.

Kulcsszavak: serdülők; „egészséghit-modell”; étkezési szokások; pszichológiai változók

\section{Summary:}

Introduction: Nowadays health maintenance and disease prevention are main social objectives. Several studies are focused on exploring aspects of healthy and unhealthy lifestyles by means of behavioral models. Among these studies those related to nutrition are highly 
important because obesity and diseases caused by unhealthy eating habits are serious public health concerns not only in our country but also worldwide. Adolescence is a very sensitive lifetime period in terms of developing appropriate eating habits due to physical and psychological changes. Therefore, the focal point of our study has been to detect factors that predict adolescents' conscious eating preference. Our goal based on the exploration of the relationships between elements of the Health Belief Model, completing with some personality factors (self-efficacy, optimism, self-control), and self-conscious eating.

Methods: Our study was going on with the participation of 440 high school students in Szeged. Thirty-seven percent of the sample were boys, average age was 16.0 years with a standard deviation of 1.2 years. For collecting data we used an online self-administered questionnaire. For statistical analysis we applied correlation and regression analysis.

Results: Our data have revealed several relationships between the elements of Health Belief Model, the psychological factors and self-conscious eating. Referring to the results of regression analysis the importance of healthy eating, the benefits of behavioral change and selfcontrol were the most and self-efficacy the least decisive positive predictors, while perceived barriers predicted negatively self-conscious eating. For boys perceived susceptibility referring to eating habits related diseases and self-efficacy had significant prediction value, for girls these variables did not act as predictors. For both sexes the importance of healthy eating was the most powerful factor.

Conclusion: From our results we can conclude that the Health Belief Model completing with some relevant psychological variables, may serve as a useful theoretical background to have better knowledge of adolescents' eating habits.

Keywords: adolescents; Health Belief Model; eating habits; psychological variables

\section{BEVEZETÉS}

Manapság köztudott, hogy a táplálkozás az életmód meghatározó eleme, amely az egészséget és az életminőséget is hosszú távon befolyásolja. A megfelelő étkezési szokások segíthetnek abban, hogy fenntartsuk egészségünket, és elkerüljünk számos krónikus betegséget. ${ }^{1} \mathrm{~A}$ kiegyensúlyozatlan táplálkozási szokások miatt olyan betegségek alakulhatnak ki, mint az elhízás², a szív- és érrendszeri megbetegedések, agyvérzés vagy cukorbetegség. ${ }^{3,4,5}$ Mivel a felnőttkori táplálkozási szokásokat korábbi életkorokban alapozzuk meg, már gyermek- és serdülökorban oda kell figyelni a helyes, egészségvédő étkezés kialakítására. A serdülők ebből a szempontból különösen veszélyeztetettek. Míg a gyermekek étkezési szokásait főként a szülők döntései határozzák meg, addig a függetlenedési törekvések miatt a serdülők táplálkozása drasztikusan megváltozhat: a szülői hatások helyett inkább a kortársak befolyásolják étkezési döntéseiket. $6,7,8$ A serdülő fiatalok nem megfelelő táplálkozási magatartása azért is jelenthet problémát, mivel a serdülőkor nagyon érzékeny életszakasz. Egyrészt a jelentős fizikai változás miatt elengedhetetlen a megfelelő tápanyagbevitel ${ }^{9}$, másrészt a táplálkozás minőségének hosszú távú egészségügyi hatásai is lehetnek. ${ }^{10}$ Számos kutatás bizonyította már, hogy a serdülókori elhízás nagymértékben előre jelzi a felnőttkori elhízást, amely az egyik legfóbb népegészségügyi probléma a fejlett országokban, köztük hazánkban is. ${ }^{11,12,13}$

Étkezési szokásainkat különböző tényezők befolyásolják, amelyek feltárására és a köztük lévő kapcsolatok megállapítására több viselkedési modell született. Ezek közül az egyik legjelentősebb az „egészséghit-modell”, amelyet az 1950-es években dolgoztak $\mathrm{ki}^{14}$, és azóta széles körben használják számos egészségmagatartás feltárására, mint például a testmozgás ${ }^{15}$, a testsúly kezelése ${ }^{16}$, a dohányzás ${ }^{17}$ és az egészséges táplálkozás. ${ }^{18} \mathrm{~A}$ modell az egészséges viselkedést befolyásoló elemek szerepét méri fel, amelyek a következők: az észlelt súlyosság és az észlelt hajlam (amelyek együttesen a fenyegetettséget mérik fel), a viselkedésváltozás haszon/korlát aránya, akciótervek, demográfiai tényezők és az énhatékonyság. Egyrészt feltételezzük, hogy az egyén elköteleződik az egészséges viselkedés mellett, ha fenyegetettséget érez arra, hogy megbetegedhet. Ez a fenyegetettség az adott 
betegség súlyosságából (pl. az étkezéssel kapcsolatban mennyire gondolja súlyosnak az elhízás problémáját), és az egyén által észlelt hajlamból (pl. menynyire tartja valószínűnek, hogy ő is túlsúlyossá válik az étkezési szokásai miatt) ered. Másrészt úgy vélhetjük, hogy a tervezett preventív magatartást meghatározza az ahhoz köthető becsült elönyök/hasznok (pl. az egyén fitt marad) és hátrányok/korlátok (pl. több időt kell szánni az ételek elkészítésére) aránya, továbbá az adott cselekvésre irányuló akciótervek (pl. iskolai kampányok és egyéb lehetőségek) is. Egyéb demográfiai tényezők és az énhatékonyság (annak hite, hogy képesek vagyunk a viselkedésváltozásra) is módosíthatják a modell elemeinek hatásait. ${ }^{19,} 20$

A táplálkozással kapcsolatban is számos kutatás megerősítette az „egészséghit-modell” hatékonyságát. ${ }^{21,22,23}$ Eredményeik tükrében úgy túnik, hogy felnőttek körében az adott egészségügyi problémára vonatkozó észlelt hajlam és az egészséges táplálkozáshoz köthető előnyök megítélésének mértéke pozitívan, míg az egészséges táplálkozáshoz kapcsolódó korlátozó tényezők túlsúlyának észlelése negatívan befolyásolják az egészséges étkezésre irányuló magatartást. ${ }^{21}$ Egy másik tanulmány egyetemisták körében is megállapította a korlátozó tényezők hasonló szerepét, emellett az énhatékonyság nagyobb elkötelezettséget eredményezett a kiegyensúlyozott táplálkozás irányában. ${ }^{24}$ Megállapítható azonban, hogy a kutatások többsége felnőttek körében készült, és keveset tudunk arról, hogy az „egészséghit-modell” milyen szerepet játszik serdülőknél. Egy tanulmányban a serdülő lányok körében az észlelt fenyegetettség, az énhatékonyság és az akciótervek kapcsolatban álltak a súlycsökkentés szándékával. ${ }^{25}$ Továbbá azok a serdülők, akik ételallergiától szenvedtek, jobban odafigyeltek az egészségükre, beleértve a táplálkozásukat is, amikor a betegségük súlyosságát nagyobb, és az egészséges magatartással járó korlátozó tényezőket kisebb mértékűnek észlelték. ${ }^{26}$ Viszont ezek a kutatások specifikus csoportokra vonatkoztak, és eddig nem találtunk olyan átfogó tanulmányt, amely általánosságban vizsgálná a serdülők körében az „egészségit-modell” relevanciáját. Az ún. étkezés-szabályozási motivációs elmélet ${ }^{27}$, valamint az étkezéssel összefüggő öndeterminációs elmélet ${ }^{28}$ alapján pszichológiai tényezők is fontos szerepet játszanak abban, hogy megértsük a serdü- lők táplálkozási szokásait. Ezek közé tartozik az „egészséghit-modellben” is már megjelenő énhatékonyság mellett az önkontroll és az optimizmus. $A z$ énhatékonyság olyan vélekedésekre vonatkozik, hogy az egyén milyen jól tudja végrehajtani azokat a cselekvéseket, amelyek a jövendőbeni helyzettel foglalkoznak ${ }^{29}$, azaz annak megítélése, hogy a jövőben mennyire képes egy adott cél érdekében hatékonyan cselekedni. Vizsgálatok alapján az énhatékonyság olyan fontos személyiségjellemző, amely általánosságban pozitívan befolyásolja a serdülők étkezési magatartását. ${ }^{30} \mathrm{~A}$ nagyobb mértékű énhatékonyság összefüggött a zöldség- és gyümölcsfogyasztással ${ }^{31}$, valamint az alacsonyabb zsírtartalmú ételek iránti preferenciával. ${ }^{32}$

Az önkontroll az egyén azon képessége, amely egy adott viselkedés megváltoztatásáért felelős, valamint elősegíti a hosszú távú célokra való törekvést. ${ }^{33}$ Az önkontroll, mivel korlátozni tudja a nem kívánt viselkedést, szintén fontos tényezője lehet az egészséges táplálkozásnak. ${ }^{34}$ Kutatások igazolták, hogy a nagyobb önkontrollal rendelkezők jobban tudják irányítani a gondolataikat, érzéseiket és impulzusaikat, míg azok, akik kisebb mértékű önkontrollal rendelkeztek, sokkal valószínúbben mutattak problémás viselkedést. ${ }^{35,36} \mathrm{Az}$ önkontroll és az étkezési magatartás vizsgálata során megállapították, hogy azok, akik nagyobb önkontrollal és kisebb impulzivitással rendelkeznek, előnyben részesítik az egészséges ételek fogyasztását, szemben azokkal, akikre ennek az ellenkezője jellemző. ${ }^{37} \mathrm{Az}$ önkontroll szerepe serdülők körében sem elhanyagolható. Kutatási eredmények alapján a kisebb mértékú önkontrollal rendelkező fiatalok sokkal valószínúbb, hogy dohányoznak, több alkoholt és zsíros ételt fogyasztanak, mint a magasabb önkontrollal bíró társaik. ${ }^{38}$ Továbbá a nagyobb önkontrollal rendelkező serdülők több egészséges nassolnivalót esznek ${ }^{7}$, illetve kevesebb pénzt költenek édességre és üdítőitalokra. ${ }^{39}$ Meg kell jegyeznünk azt is, hogy az önkontroll szerepe nem egyértelmű az egészséges táplálkozás elősegítésével kapcsolatban. Míg az egyik vizsgálat szerint az önkontroll kapcsolatban állt a nagyobb mértékű zöldség- és gyümölcsfogyasztással ${ }^{40}$, addig mások ezt a kapcsolatot nem igazolták. ${ }^{41}$ Ezek alapján valószínűsíthető, hogy az önkontroll nem mindig direkt, hanem inkább indirekt szerepet tölthet be az egészséges táplálkozásban. ${ }^{42}$ 
Végül az optimizmus szerepe sem elhanyagolható az egészséges táplálkozás fenntartásában. Optimizmus alatt olyan, jövőbeni elvárásokra vonatkozó attitűdöt értünk, amelyet az egyén kívánatosnak tart saját hasznára vagy örömére. ${ }^{43}$ Eredmények szerint az optimistább nőknek alacsonyabb volt a testtömegindexe (Body Mass Index, BMI) ${ }^{44}$, valamint általánosságban is nagyobb mértékű optimizmus volt jellemző az egészségesebb ételeket fogyasztók körében. ${ }^{45}$ Továbbá az optimizmus növelte, míg a pesszimizmus csökkentette a zöldség- és gyümölcsfogyasztás gyakoriságát, illetve kapcsolatban állt több egészségtelen étel fogyasztásával is. ${ }^{46}$ Serdülőkorban azonban az optimizmus irreális is lehet, ami az egészségtelen étkezéshez kapcsolódó kockázatok alulbecsléséhez vezethet. ${ }^{47}$ Úgy gondoljuk, hogy az eddigi eredmények alapján fontos tovább vizsgálni serdülók étkezési magatartását e szempontok figyelembevételével. Ehhez jelen tanulmányunkban azt a célt tûztük ki, hogy az „egészséghit-modell” elemeinek segítségével és a bemutatott pszichológiai változók felhasználásával megvizsgáljuk a fiatalok jelenlegi étkezési szokásait. Vizsgálatunk során arra a kérdésre kerestük a választ, hogy ezek a tényezők milyen mértékben befolyásolják az étkezési szokásaikat, milyen kapcsolat állapítható meg a változók között. További célkitúzésünk volt, hogy feltérképezzük, hogy tapasztalhatók-e nemi különbségek a vizsgált területen.

\section{MÓDSZERTAN}

Vizsgálatunkban 440 szegedi középiskolás vett részt 2018-2019-ben. A résztvevők 37\%-a fiú volt, életkoruk 14-19 év közé esett (átlag: 16,0, szórás: 1,2 év). $\mathrm{Az}$ adatok gyűjtését online kérdőívvel végeztük 2018 novembere és 2019 januárja között, informatikai vagy délutáni tanóra keretében, a kitöltés körülbelül 15-20 percet vett igénybe. A részvétel önkéntes és anonim volt. Kérdőívünk a szociodemográfiai kérdések mellett tartalmazott az „egészséghit-modellre" vonatkozó, illetve az étkezési szokásokkal kapcsolatos kérdéseket. Továbbá három pszichológiai faktort is bevontunk az elemzésbe: az énhatékonyságot, az optimizmust és az önkontrollt. Az "egészséghit-modell” elemeihez kapcsolódó kérdéseket Deshpande, Basil és Basil (2009) kutatásából ${ }^{18}$ adaptáltuk.
Függő változónak a tudatos étkezést választottuk, amely az egészséges ételek preferenciáján alapult. Ezzel kapcsolatban négy kérdést tettünk fel. ${ }^{18}$

1) Véleményed szerint az elmúlt két hétben az általad fogyasztott ételek mennyire voltak tápanyagban gazdagok?”, 2) „Az elmúlt két hétben az általad fogyasztott ételek mennyire voltak egészségesek?", 3) „Az elmúlt két hét folyamán milyen gyakran választottál egészséges ételeket?”, 4) „Az elmúlt két hét folyamán milyen gyakran választottál egészségtelen ételeket?". A válaszokat 7-fokú Likert-skálán mértük ( 1 = egyik étel sem, 7 = minden étel, valamint 1 = soha, 7 = mindig; az utolsó kérdésnél inverz értékelést alkalmaztunk). A megbízhatóságot mérő Cronbach-alfa értéke 0,81-nek bizonyult.

Független változókként a részben az étkezéssel összefüggő faktorok (észlelt súlyosság, észlelt hajlam, észlelt hasznok és korlátok, fontosság), részben a pszichológiai változók (énhatékonyság, optimizmus, önkontroll) szerepeltek.

Az észlelt súlyosság mérésére hét állitást használtunk $^{18}$, amelyet bevezető mondat előzött meg: „A rossz étkezési szokásaim miatt tartok attól, hogy az életem során...”: 1) „... több mint két hónapot hiányozni fogok az iskolából/munkából.”, 2) „... hosszú távú hatásai lesznek.”, 3) „... hosszú ideig ágyhoz leszek kötve.”, 4) „... orvosi kiadásaim lesznek.", 5) „... hátráltatja az előmenetelemet.”, 6) „... megszenvedik a társas kapcsolataim.”, 7) „... rossz hatása lesz a családi életemre.". A válaszokat hétfokú Likert-skálán mértük ( 1 = egyáltalán nem értek egyet, 7 = teljes mértékben egyetértek). A mérőeszköz megbízhatósága (Cronbach-alfa) jelen esetben 0,89 volt.

$A z$ észlelt hajlamot öt kérdéssel mértük ${ }^{18,30}$, amelyek szintén bevezetővel kezdődtek: „Szerinted mekkora annak a kockázata, hogy...”: 1) „komolyan megbetegszel, ha nem táplálkozol egészségesen", 2) „táplálkozási szokásaid miatt magasvérnyomásbetegséged lesz életed során?”, 3) „táplálkozási szokásaid miatt magas koleszterinszinted lesz életed során?”, 4) „táplálkozási szokásaid miatt rákos megbetegedésed lesz életed során?", valamint 5) „táplálkozási szokásaid miatt cukorbetegséged lesz életed során?". A válaszokat szintén hétfokú Likert-skálán mértük ( 1 = szinte semmi, 7 = valószínū). A skála megbízhatónak bizonyult (Cronbachalfa $=0,85$ ).

$\mathrm{Az}$ észlelt haszon változóhoz tartozó kérdésre („Számomra az, hogy az elkövetkező két hét nagy 
részében egészségesen táplálkozzak ... , ... lenne.") öt válaszpár tartozott. ${ }^{18} 1$ ) káros/ előnyös, 2) kellemetlen/ kellemes, 3) rossz / jó, 4) értéktelen/ értékes, 5) élvezhetetlen / élvezetes. Hétfokú Likertskálán kellett eldönteni, hogy a válaszok melyik része igaz inkább a kitöltőre. A megbízhatóság mértéke (Cronbach-alfa) 0,88 volt.

Az észlelt korlátokat három állítással tártuk fel, amelyekre hétfokú Likert-skálán kellett választ adniuk (1 = egyáltalán nem értek egyet, 7 = teljes mértékben egyetértek). ${ }^{18} \mathrm{Az}$ állítások a következők voltak: 1) „Nem szeretem a legtöbb egészséges étel izét.", 2) „Úgy vélem, túl sok időt venne igénybe az elkövetkező két hétben, hogy megváltoztassam a táplálkozási szokásaimat azért, hogy azok egészségesebbek legyenek.", 3) „Úgy vélem, nehéz lenne az elkövetkező két hét után, hogy megváltoztassam a táplálkozási szokásaimat azért, hogy azok egészségesebbek legyenek." Cronbach- alfa: 0,78.

Az étkezési szokásokhoz kapcsolódóan továbbá arra kerestük a választ, hogy mennyire tartják fontosnak az egészséges táplálkozást. Ehhez két kérdés tartozott:18 1) "Mennyire fontos számodra, hogy tápanyagban gazdag ételeket fogyassz?", 2) "Mennyire fontos számodra az egészséges táplálkozás, amikor élelmiszert vásárolsz?". Hétfokú Likert-skálán kellett megjelölni, hogy az állítással mennyire ért egyet a kitöltő ( 1 = egyáltalán nem, 7 = nagyon fontos $)$. A Cronbach-alfa értéke: 0,74 lett.

A pszichológiai változók közül az én-hatékonyságot a 10 állításból álló Énhatékonyság Skála validált magyar verziójával mértük. ${ }^{46} \mathrm{~A}$ kitöltő egy négypontos skálán jelöli, hogy mennyire jellemző rá az adott állítás ( 1 = egyáltalán nem jellemző, $4=$ teljesen jellemző). Saját mintánkon a megbízhatósági mutató (Cronbach-alfa) 0,86 lett. Az optimizmus feltárására A Life Orientation Test (LOT) ${ }^{47}$ magyar verzióját alkalmaztuk. ${ }^{48}$ A skála 10 állításával kapcsolatos egyetértést ötfokú Likert-skálán kellett bejelölni. A magasabb összpontszám az optimizmusra, míg az alacsonyabb pesszimista hozzáállásra utal. A mérőeszköz megbízhatósága (Cronbach-alfa): 0,66 lett. $\mathrm{Az}$ önkontrollt Tangney, Baumeister és Boone (2004) ún. Önkontroll skálájával ${ }^{49}$ mértük, amely szintén 10 itemből áll. Ötfokú Likert-skálán kellett megjelölni, hogy az állítás mennyire jellemző a kitöltőre ( 1 = egyáltalán nem jellemző rám, 5 = teljesen jellemző rám). A skála megbízhatósági mutatója a saját mintán: 0,79.
Statisztikai elemzésünk során először korrelációanalízissel a változók közötti kétoldalú kapcsolatokat, illetve független mintás t-próbával a változók közötti nemi különbségeket vizsgáltuk meg. Majd a tudatos étkezést használtuk függő változóként. Többváltozós lineáris regresszióelemzéssel tártuk fel az egész mintára, valamint nemekre vonatkozóan külön-külön, hogy az „egészséghit-modell” elemei, valamint a pszichológiai faktorok mekkora mértékben befolyásolják a jelenlegi étkezési státuszra jellemző tudatos étkezést.

\section{EREDMÉNYEK}

Elemzésünk során először a vizsgált változók közötti kétoldalú kapcsolatokat tártuk fel. Az 1. táblázat tartalmazza a korrelációs együtthatókat. Az „egészségit-modell” elemei a következőképpen álltak kapcsolatban egymással: az észlelt hajlam és az észlelt súlyosság erős, szignifikánsan pozitív kapcsolatot mutatott egymással $(r=0,44, p<0,01)$. $A z$ észlelt haszon és az észlelt korlátok közepesen erős, szignifikánsan negatív kapcsolatban álltak $(r=-0,36, p<0,01)$. Ezen kívül az észlelt korlátok változója az észlelt súlyossággal $(r=0,10, p<0,05)$ és az észlelt hajlammal $(r=0,12, p<0,05)$ mutatott kismértékű szignifikáns kapcsolatot. A pszichológiai változók közepesen erős, szignifikánsan pozitív kapcsolatban álltak egymással. Az optimizmus nagyobb mértéke együtt járt a magasabb fokú énhatékonysággal $(r=0,31, p<0,01)$ és önkontrollal $(r=0,30$, $p<0,01)$. Továbbá az önkontroll magasabb mértéke nagyobb fokú énhatékonysággal állt kapcsolatban $(r=0,29, p<0,01)$. A pszichológiai változók és az „egészséghit-modell” egyes elemei között is együttjárás tapasztalható. Az énhatékonyság és az észlelt haszon között szignifikáns pozitív kapcsolatot tártunk fel $(r=0,21, p<0,01)$. Az optimizmus az észlelt haszonnal $(r=0,26, p<0,01)$ pozitív, míg az észlelt súlyossággal $(r=-0,16, p<0,01)$, az észlelt hajlammal $(r=-0,12, p<0,05)$ és az észlelt korlátokkal $(r=-0,19, p<0,01)$ negatív kapcsolatban állt. Az önkontroll és az észlelt haszon között pozitív $(r=0,22$, $p<0,01$ ), valamint az önkontroll és az észlelt súlyosság $(r=-0,11, p<0,05)$ és észlelt korlátok között negatív ( $r=-0,23, p<0,01)$ kapcsolat állapítható meg. Végül az egészséges étkezés fontossága pozitívan korrelált az énhatékonysággal $(r=0,24$, 
$p<0,01)$, az optimizmussal $(r=0,29, p<0,01)$, az önkontrollal ( $r=0,23, p<0,01)$, az észlelt haszonnal $(r=0,41, p<0,01)$, valamint negatív kapcsolatban állt az észlelt korlátokkal ( $r=-0,37, p<0,01)$.

A tudatos étkezés szignifikánsan pozitív kapcsolatot mutatott az énhatékonysággal ( $r=0,26, p<0,01)$, az optimizmussal $(r=0,28, p<0,01)$, az önkontrollal ( $r=0,33, p<0,01)$ és az egészséges táplálkozás fontosságával ( $r=0,54, p<0,01)$, valamint negatívan korrelált az észlelt korlátokkal $(r=-0,42$, $p<0,01)$. Nemi különbséget találtunk az észlelt súlyosság [t(378) $=-2,02, p=0,04]$, és az észlelt elönyök $[\mathrm{t}(438)=-3,70, p<0,01]$ tekintetében: mindkét esetben a lányok értékei voltak nagyobbak [1. táblázat].

1. táblázat: $A$ változók leiró statisztikája és korrelációelemzése ( $N=440)$

\begin{tabular}{|c|c|c|c|c|c|c|c|c|c|}
\hline & $\begin{array}{c}\text { Átlag } \\
\text { (Szórás) }\end{array}$ & 1 & 2 & 3 & 4 & 5 & 6 & 7 & 8 \\
\hline 1. Észlelt súlyosság & $\begin{array}{l}15,6 \\
(9,3)\end{array}$ & - & & & & & & & \\
\hline 2. Észlelt hajlam & $\begin{array}{l}19,0 \\
(7,1)\end{array}$ & $0,44^{* *}$ & - & & & & & & \\
\hline 3. Észlelt haszon & $\begin{array}{l}28,3 \\
(5,9)\end{array}$ & 0,01 & 0,03 & - & & & & & \\
\hline 4. Észlelt korlátok & $\begin{array}{c}8,7 \\
(4,5)\end{array}$ & $0,10^{*}$ & $0,12^{*}$ & $-0,36 * *$ & - & & & & \\
\hline 5. Énhatékonyság & $\begin{array}{l}29,6 \\
(5,2)\end{array}$ & $-0,05$ & $-0,72$ & $0,21^{* *}$ & $-0,08$ & - & & & \\
\hline 6. Optimizmus & $\begin{array}{l}19,6 \\
(4,4)\end{array}$ & $-0,16 * *$ & - & $0,26 * *$ & $-0,19 * *$ & $0,31^{* *}$ & - & & \\
\hline 7. Önkontroll & $\begin{array}{c}3,0 \\
(0,7)\end{array}$ & $-0,11^{*}$ & $-0,08$ & $0,22 * *$ & $-0,23 * *$ & $0,29 * *$ & $0,30 * *$ & - & \\
\hline 8. Fontosság & $\begin{array}{l}10,4 \\
(2,5)\end{array}$ & $-0,17$ & 0,07 & $0,41 * *$ & $-0,37^{* *}$ & $0,24^{* *}$ & $0,29 * *$ & $0,23^{* *}$ & - \\
\hline 9. Tudatos étkezés & $\begin{array}{l}18,4 \\
(3,8)\end{array}$ & $-0,08$ & $-0,08$ & 0,41 & $-0,42 * *$ & $0,26 * *$ & $0,28 * *$ & $0,33^{* *}$ & $0,54^{* *}$ \\
\hline
\end{tabular}

Forrás: saját szerkesztés. ${ }^{*} p<0,05,{ }^{* *} p<0,01$

2. táblázat: Az „egészséghit-modell” változóinak és egyéb pszichológiai változók szerepe a tudatos étkezésben: többváltozós linerális regresszióelemzés

\begin{tabular}{|c|l|l|l|l|}
\hline Független változók & \multicolumn{2}{|c|}{ Összesen } & \multicolumn{1}{|c|}{ Lányok } \\
\hline & \multicolumn{2}{|c|}{ Standardizált regressziós együttható $(\beta)$} \\
\hline Észlelt súlyosság & $-0,01$ & 0,09 & $-0,05$ \\
\hline Észlelt hajlam & $-0,06$ & $-0,14^{*}$ & $-0,02$ \\
\hline Észlelt haszon & $0,15^{* * *}$ & $0,15^{* *}$ & $0,15^{* *}$ \\
\hline Észlelt korlátok & $-0,19^{* * *}$ & $-0,18^{* *}$ & $-0,21^{* * *}$ \\
\hline Énhatékonyság & $0,07^{*}$ & $0,14^{* *}$ & 0,05 \\
\hline Optimizmus & 0,03 & $-0,01$ & 0,05 \\
\hline Önkontroll & $0,13^{* *}$ & $0,18^{* *}$ & $0,11^{* *}$ \\
\hline Fontosság & $0,36^{* * *}$ & $0,29 * * *$ & $0,38^{* * *}$ \\
\hline $\mathrm{R}^{2}$ & 0,41 & 0,39 & 0,44 \\
\hline
\end{tabular}

Forrás: saját szerkesztés. ${ }^{*} p<0,05,{ }^{*} p<0,01$ 
3. táblázat: Kollinearitás-vizsgálat a többváltozós regresszióelemzéshez

\begin{tabular}{|c|c|c|c|c|c|c|}
\hline \multirow{2}{*}{ Függelten változók } & \multicolumn{2}{|c|}{ Összesen } & \multicolumn{3}{c|}{ Fiúk } & \multicolumn{2}{c|}{ Lányok } \\
\cline { 2 - 8 } & VIF & Tolerancia & VIF & Tolerancia & VIF & Tolerancia \\
\hline Észlelt súlyosság & 1,27 & 0,79 & 1,32 & 0,76 & 1,28 & 0,78 \\
\hline Észlelt hajlam & 1,29 & 0,78 & 1,33 & 0,75 & 1,28 & 0,78 \\
\hline Észlelt haszon & 1,33 & 0,75 & 1,17 & 0,86 & 1,57 & 0,64 \\
\hline Észlelt korlátok & 1,28 & 0,78 & 1,35 & 0,74 & 1,30 & 0,77 \\
\hline Énhatékonyság & 1,20 & 0,84 & 1,31 & 0,77 & 1,21 & 0,82 \\
\hline Optimizmus & 1,26 & 0,79 & 1,34 & 0,75 & 1,25 & 0,80 \\
\hline Önkontroll & 1,21 & 0,83 & 1,15 & 0,83 & 1,29 & 0,77 \\
\hline Fontosság & 1,39 & 0,72 & 1,48 & 0,68 & 1,50 & 0,67 \\
\hline
\end{tabular}

Forrás: saját szerkesztés. Tolerancia és VIF (Variance Inflation Factor), a kollinearitás mérőszámai

A 2. táblázat a többváltozós lineáris regresszióelemzés eredményeit mutatja a tudatos étkezés (mint függő változó) és a többi (független) változó között. Látható, hogy a teljes mintát tekintve a jelenlegi tudatos étkezést pozitív irányban legnagyobb mértékben a fontosság $(\beta=0,36, p<0,01)$ jelezte előre, továbbá az észlelt haszon $(\beta=0,15, p<0,01)$, az önkontroll $(\beta=0,13, p<0,05)$, és kismértékben az énhatékonyság $(\beta=0,07, p<0,1)$. Ezzel szemben negatív irányú prediktornak mondható az észlelt korlátok változója $(\beta=-0,19, p<0,01)$. A nemeket külön vizsgálva is hasonló összefüggéseket állapíthatunk meg, azzal a különbséggel, hogy a fiúknál szignifikáns jósló erővel rendelkezett az észlelt hajlamot mérő változó $(\beta=-0,14, p<0,1)$, valamint az énhatékonyság $(\beta=0,14, p<0,05)$, míg a lányoknál ezek a változók nem szerepeltek prediktorként. Mindkét nemnél az egészséges ételek fogyasztásának fontossága volt a legerősebb tényező. Ezek a változók az egész mintán a variancia $41 \%$-át, a fiúknál 39\%-át, a lányoknál pedig 44\%-át magyarázták meg. A modellek megbízhatóságát a VIFmutatóval (Variance Inflation Factor) is megvizsgáltuk, amely alapján a VIF értékek az elfogadható tartományon belül maradtak (<2). [3. táblázat]

\section{MEGBESZÉLÉS ÉS KÖVETKEZTETÉS}

Jelen vizsgálatunkban arra kerestük a választ, hogy a serdülők tudatos étkezését hogyan befolyásolják az „egészséghit-modell” elemei, kiegészítve egyes pszichológiai változókkal.
A vizsgált változók közötti korrelációs kapcsolatok feltárása során megállapíthatjuk, hogy a fenyegetettséget meghatározó észlelt hajlam és súlyosság pozitív kapcsolatban álltak egymással. Az egyén tehát minél nagyobb mértékben gondolja, hogy ki van téve egy betegségnek, valamint minél nagyobb mértékben tartja ezt a betegséget súlyosnak, annál nagyobbnak észleli saját fenyegetettségét. ${ }^{14,18} \mathrm{Ez}$ azért lényeges, mert intervenciós vizsgálatokban, pl. hipertóniás betegek körében végzett étkezési tanácsadás során a betegek életmódbeli változtatására nagyobb az esély, ha felismerik saját veszélyeztetettségüket. ${ }^{50}$ Serdülők esetében ezt azért nehezebb megvalósítani, mert ők még kevésbé érzik érintettnek magukat, a jövőbeli kockázatokat hajlamosak alulértékelni. Jelen vizsgálatban az optimizmus mindkét változóval negatív kapcsolatban állt, azonban az utóbbi pszichológiai változó a tudatos étkezéssel is pozitív összefüggést mutatott; ennek alapján arra következtethetünk, hogy ez az optimizmus reális, és azért érzik magukat kevésbé fenyegetettnek a negatív következményektől, mert valóban törekszenek az egészséges étkezésre. Korábbi vizsgálatok is arra engednek következtetni, hogy a serdülők kockázatészlelése sokkal reálisabb, mint azt korábban feltételeztük. ${ }^{51}$

A betegség megelőzésére irányuló viselkedésváltozásból származó észlelt hasznok és korlátok ellentétesen viszonyultak egymáshoz. Ezek alapján valószínűsíthető, hogy az, aki a viselkedésváltozás pozitívumait részesíti előnyben, kevésbé veszi számításba a változást akadályozó korlátokat. 
Ezek a korlátok eredményeink szerint az észlelt fenyegetettséggel is pozitív kapcsolatban állnak. Ráadásul a korlátokat jellemző változó mind a tudatos étkezéssel, mind pedig az egészséges étkezés fontosságával negatív kapcsolatot mutat, ugyanakkor a haszon nevű változóval ezek az összefüggések pozitívak. Mivel keresztmetszeti vizsgálatról van szó, ok-okozati viszonyt nem tudunk igazolni, feltételezhető, hogy azok, akik a korlátokat észlelik, kevésbé hajlandók tudatosan egészségesen étkezni, míg a haszonra figyelők számára ez fontosabb, és törekednek is rá. Hasonló eredmények alátámasztják jelen megállapításunkat, miszerint az észlelt haszon pozitívan, míg az észlelt korlátok negatívan befolyásolják az egészségviselkedést. ${ }^{21,24,26}$

A pszichológiai változókat tekintve elsőként érdemes kiemelni, hogy azok, akik úgy vélik, hogy sikeresebben megbirkóznak a problémákkal, képesek jobban uralkodni a cselekvéseiken, valamint optimistábbak is. Az énhatékonyság, az önkontroll és az optimizmus magasabb szintje a vizsgált serdülők körében az adott viselkedés iránti előnyök/hasznok preferenciáját eredményezheti. Továbbá azok a serdülők, akik optimistábbak, kevésbé gondolják azt, hogy hajlamosak megbetegedni. Szintén jellemző, hogy a nagyobb önkontrollal rendelkező serdülők kevésbé észlelik a viselkedésváltozás okozta korlátokat. Ezek az eredmények megerősítik a korábbi kutatások megállapításait. 24,30,37,44

A tudatos étkezés többváltozós regresszióelemzésének eredményei alapján megállapíthatjuk, hogy serdülők körében az egészséges táplálkozásra törekvést legerősebben az jelzi előre, ha a serdülő fontosnak tartja az egészséges táplálkozást. Emellett az önkontrollnak és az énhatékonyság magasabb szintjének lehet meghatározó szerepe, amit korábbi vizsgálatok is megerősítenek. ${ }^{31,32,38,39,40}$ Az optimizmus nem játszik szerepet a többváltozós elemzésben; úgy tûnik, jelentősége inkább az észlelt fenyegetettség szintjének kalibrálásában mutatkozik meg.

A nemek szerinti elemzésből megállapítható, hogy a fiúk egészséges táplálkozásában szerepet játszhat az, hogy az egészségtelen táplálkozásból eredő megbetegedésekkel kapcsolatban mekkora hajlamot tulajdonítanak maguknak. Itt szintén utalni kell arra, hogy ok-okozati viszony jelen adatokból nem erősíthető meg, azonban feltételezhető, hogy a tudatos étkezés hiánya mutat összefüggést a nagyobb észlelt fenyegetettséggel (negatív előjel). Ez reális kockázatészlelésre utal, azaz tudatában vannak annak, hogy amennyiben nem étkeznek tudatosan, megnövekedett betegségkockázatnak vannak kitéve a későbbiekben. Lányoknál ez a jelenség nem igazolható. Ez korábbi kutatási eredményeknek is megfelel; a lányok kedvezőbb egészségmagatartása kisebb egészségkockázatot jelent, s ezzel tisztában is vannak. ${ }^{48}$ Szintén a fiúkra jellemző, hogy az énhatékonyság, általános problémamegoldó készség meghatározó számukra a tudatos étkezés preferálásában; a lányoknál ez a változó nem befolyásolja az étkezést. Annak ellenére, hogy az énhatékonyság pontszámaiban nem volt jelentős nemi eltérés, úgy tûnik, a fiúknak nagyobb szükségük van a tudatos ételválasztáshoz arra, hogy bízzanak önmagukban. Első helyen azonban mindkét nem esetében a fontosság állt.

Kutatásunk korlátjaként meg kell említenünk, hogy mintánk nem reprezentálja a teljes hazai serdülő populációt, amely az eredmények általánosítását így nem teszi lehetővé. Amint azt már több helyen is említettük, mivel adatfelvételünk keresztmetszeti jellegú, ok-okozati összefüggés igazolására nem alkalmas. Jelenleg önbevalláson alapuló módszerrel mértük fel az étkezési magatartást, amelyet a jövőben a validitás fokozása érdekében bővíteni lehetne interjúkkal vagy táplálkozási napló alkalmazásával. Fontos azt is megjegyezni, hogy bár az „egészséghitmodell" korábbi és jelen kutatásunkban is hasznosnak bizonyult, a modell egyik alapvető kritikája, hogy kizárólag az egyéni, és szinte kizárólag a kognitív tényezőket veszi figyelembe, miközben a legtöbb esetben nem ezek, vagy nem csupán ezek befolyásolják táplálkozási szokásainkat. Serdülőket vizsgálva ez különösen fontos lehet, hiszen más hatás (pl. szülői befolyás vagy az iskolai étkeztetés jellege) is meghatározó lehet az ételválasztásukban, mint ahogy a motivációk széles skálája vagy egyéb környezeti tényezők is, amit korábbi vizsgálatok igazoltak. ${ }^{52,53,54}$ Ugyanakkor kutatásunk erőssége, hogy az „egészséghit-modell” számos elemét teszteltük a serdülők tudatos étkezésével kapcsolatban, kiegészítve néhány fontos pszichológiai változóval. A serdülők jelentik azt a korosztályt, ahol az étkezési preferencia a gyermekkor után már kevésbé függ a külső körülményektől, ezért érdemes ételpreferenciájukat e modell segítségével is elemezni. E tekintetben a vizsgálatunk beváltotta a hozzá füzött reményeket, és további kutatásokra ösztönöz. 
Összegezve elmondható, hogy eredményeink alapján a serdülők többnyire reálisan látják saját fenyegetettségüket az étkezésük egészséges vagy egészségtelen jellege alapján; ugyanakkor ez még nem elég ahhoz, hogy hosszabb távon gondolkodjanak, és változtassanak étkezési szokásaikon. Azok a serdülők, akik fontosnak tartják az egészséges táplálkozást, tudatosan törekszenek is arra, hogy egészséges ételeket fogyasszanak, ennek hasznát is látják, ráadásul rendelkeznek megfelelő önkontrollal, optimizmussal és énhatékonysággal, hogy ezt fenntartsák. Azok azonban, akik nem tartják ezt fontosnak, nem is törekszenek rá, és inkább a korlátokat tartják szem előtt, ami megakadályozza őket a változtatásban. A serdülő fiúk különösen veszélyeztetettek, hiszen, ha nem rendelkeznek megfelelő énhatékonysággal, nem bíznak eléggé saját döntési képességeikben, kevésbé törekszenek egészséges táplálkozásra, még akkor sem, ha egyébként reálisan látják a jövőbeli kockázatokat. Mindezek alapján arra következtethetünk, hogy az "egészséghit-modell” megfelelő elméleti háttér lehet a serdülők étkezési magatartásának megismerésére. Továbbá hasznos lehet a modellt egyéb pszichológiai tényezőkkel is kiegészíteni, amelyek szintén szerepet játszhatnak az egészséges ételvá- lasztásban. Vizsgálatunk eredményei a későbbiekben iskolai prevenciós programokban is felhasználhatók, mivel igazolják, hogy az „egészséghit-modell” elemei, valamint az önkontroll és az énhatékonyság szerepet játszanak az egészséges táplálkozásban. Iskolapszichológus vagy mentálhigiénikus bevonásával indokolt lehet a fiatalok énhatékonyságának és önkontrolljának a fejlesztése. Fontos lenne továbbá ezen programok keretében az észlelt fenyegetettség megismerése érdekében az egészségkockázatok megbeszélése, valamint az észlelt hasznok és korlátok közös feltárása. Ezen túl eredményes lehet az egészséges táplálkozásról való beszélgetés is, főként az egyéni motivációkat elötérbe helyezve, amely során megismerhetnék, hogy ki mi alapján választja meg az ételeit, és mit tesz azért, hogy egészségesen táplálkozzon, valamint ennek esetleges akadályait is.

Jövőbeli kutatásokban az étkezési magatartás részletesebb és sokoldalúbb feltárása is célszerű lenne, hiszen a hiedelmek, a meggyőződések és a motivációk, valamint a korlátok megismerése ugyanolyan fontos, mint a tényleges ételválasztás elemzése. Mivel a serdülők táplálkozási szokásainak alakulása hosszú távon is meghatározó egészségi állapotuk alakulásában, vizsgálatuk prioritást kell, hogy élvezzen.

\section{HIVATKOZÁSOK}

\footnotetext{
${ }^{1}$ Ross A, Caballero B, Cousins R, et al. Modern nutrition in health and disease. Lippincott Williams \& Wilkins, Philadelphia, 2014.

2 Nishtar S, Gluckman P, Armstrong T. Ending childhood obesity: a time for action. Lancet 2016;387(10021):825-7. doi: 10.1016/S0140-6736(16)00140-9

${ }^{3}$ Kelsey M, Zaepfel A, Bjornstad P, et al. Age-related consequences of childhood obesity. Gerontology 2014;60(3):222-8. doi: 10.1159/000356023

${ }^{4}$ McCrindle B. Cardiovascular consequences of childhood obesity. Can J Cardiol 2015;31(2):124-30. doi: 10.1016/j.cjca.2014.08.017

${ }^{5}$ Needlman R. Food marketing to children and youth: threat or opportunity? J Dev Behav Pediatr 2009;30(2):183. doi: 10.1097/01.DBP.0000349916.04784.91

${ }^{6}$ Ali MM, Amialchuk A, Heiland FW. Weight-related behavior among adolescents: The role of peer effects. PLOS ONE 2011;6(6):e21179. doi: 10.1371/journal.pone.0021179

${ }^{7}$ Robinson E, Tobias T, Shaw $L$, et al. Social matching of food intake and the need for social acceptance. Appetite 2011;65(3):747-52. doi: 10.1016/j.appet.2011.03.001

${ }^{8}$ Loth K, MacLehose R, Bucchianeri M, et al. Predictors of dieting and disordered eating behaviors from adolescence to young adulthood. J Adolesc Health 2014;55(5):705-12. doi: 10.1016/j.jadohealth.2014.04.016

${ }^{9}$ Amine EK, Baba NH, Belhadj M, et al. (2003). Diet, nutrition and the prevention of chronic diseases.

World Health Organization - Technical Report Series. doi: 10.1016/S0031-3025(16)36541-2

${ }^{10}$ Corkins MR, Daniels SR, de Ferranti SD, et al. (2016). Nutrition in children and adolescents. Med Clin North Am 2016;100(6):1217-35. doi: 10.1016/j.mcna.2016.06.005
} 
${ }^{11}$ Nishtar S, Gluckman P, Armstrong T. Ending childhood obesity: A time for action. Lancet 2016; 378(10021):825-7. doi: 10.1016/S0140-6736(16)00140-9

12 Simmonds M, Llewellyn A, Owen CG, et al. Predicting adult obesity from childhood obesity: A systematic review and meta-analysis. Obes Rev 2015;17(2):95-107. doi: 10.1111/obr.12334

${ }^{13}$ Verhagen $\mathrm{H}$, van Loveren $\mathrm{H}$. Status of nutrition and health claims in Europe by mid 2015. Trends Food Sci Technol 2016;56(1):39-45. doi: 10.1016/j.tifs.2016.07.005

${ }^{14}$ Rosenstock I. The Health Belief Model and preventive health behavior. Health Educ Monogr 1974;2(4):354-86. doi: $10.1177 / 109019817400200405$

${ }^{15}$ King K, Vidourek R, English L, et al. Vigorous physical activity among college students: using the health belief model to assess involvement and social support. Arch Exerc Health Dis 2014;4(2):267-79. doi: 10.5628/aehd.v4i2.153 ${ }^{16}$ McArthur LH, Riggs A, Uribe F, et al. Health Belief Model offers opportunities for designing weight management interventions for college students. J Nutr Educ Behav 2018;50:485-93. doi: 10.1016/j.jneb.2017.09.010

${ }_{17}$ Sharifirad G, Charkazi A, Moodi M, et al. Factors affecting cigarette smoking based on health-belief model structures in pre-university students in Isfahan, Iran. J Educ Health Promot 2014;3(1):23. doi: 10.4103/2277-9531.127614

${ }^{18}$ Deshpande S, Basil M, Basil D. Factors influencing healthy eating habits among college students: an application of the Health Belief Model. Health Mark Q 2009;26(2):145-64. doi: 10.1080/07359680802619834

${ }^{19}$ Bandura A. Self-efficacy: The exercise of control. W.H. Freeman, New York, 2012.

${ }^{20}$ Rosenstock I, Strecher V, Becker M. Social Learning Theory and the Health Belief Model. Health Educ Q 1988;15(2):175-83. doi: 10.1177/109019818801500203

${ }^{21}$ Wang E, Li Y. The effect of stress and visible health problems on the intent to continue health food consumption. Br Food J 2015;117(1):302-17. doi: 10.1108/BFJ-09-2013-0275

${ }^{22}$ Chew F, Palmer S, Kim S. Testing the influence of the Health Belief Model and a television program on nutrition behavior. Health Commun 1998;10(3):227-45. doi: 10.1207/s15327027hc1003 3

${ }^{23}$ Schafer R, Schafer E, Bultena G, et al. Food safety: An application of the health belief model. J Nutr Educ 1993;25(1):17-24. doi: 10.1016/S0022-3182(12)80183-X

${ }^{24}$ Von Ah D, Ebert S, Ngamvitroj A, et al. Predictors of health behaviours in college students. J Adv Nurs 2004;48(5):463-74. doi: 10.1111/j.1365-2648.2004.03229.x

${ }^{25}$ Park D. Utilizing the Health Belief Model to predicting female middle school students' behavioral intention of weight reduction by weight status. Nutr Res Pract 2011;5(4):337-48. doi: 10.4162/nrp.2011.5.4.337

${ }^{26}$ Jones $\mathrm{C}$, Smith H, Frew A, et al. Explaining adherence to self-care behaviours amongst adolescents with food allergy: A comparison of the health belief model and the common sense self-regulation model. Br J Health Psychol 2013;19(1):65-82. doi: 10.1111/bjhp.12033

${ }^{27}$ Verstuyf J, Vansteenkiste M, Soetens B, et al. Motivational dynamics underlying eating regulation in young and adult female dieters: Relationships with healthy eating behaviours and disordered eating symptoms. Psychol Health 2016;31(6):711-29. doi: 10.1080/08870446.2016.1143942

${ }^{28}$ Leblanc $V$, Bégin C, Corneau L, et al. Gender differences in dietary intakes: What is the contribution of motivational variables? J Hum Nutr Diet 2015;28(1):37-46. doi: 10.1111/jhn.12213

${ }^{29}$ Bandura A. Self- efficacy mechanism in human agency. American Psychologist 1982; 37(2):122-147. doi: 10.1037/0003-066X.37.2.122

${ }^{30}$ Renner B, Schwarzer R. The motivation to eat a healthy diet: How intenders and nonintenders differ in terms of risk perception, outcome expectancies, self-efficacy, and nutrition behavior. Pol Psychol Bull 2005; 36(1): 7-15.

${ }^{31}$ Burg J, Lechner L, de Vries H. Psychosocial determinants of fruit and vegetable consumption. Appetite 1995; 25(3): 285-96. doi: 10.1006/appe.1995.0062

32 Parcel GS, Edmundson E, Perry CL, et al. Measurement of self-efficacy for diet-related behaviors among elementary school children. J Sch Health 1995;65(1):23-7. doi: 10.1111/j.1746-1561.1995.tb03335.x

${ }^{33}$ Baumeister R, Vohs KD, Tice DM. The strength model of self-control. Curr Dir Psychol Sci 2007;16(6):351-5. doi: 10.1111/j.1467-8721.2007.00534.x

${ }^{34}$ Tangney JP, Baumeister RF, Boone AL. High self-control predicts good adjustment, less pathology, better grades, and interpersonal success. J Pers 2004;72(2):271-324. doi: 10.1111/j.0022-3506.2004.00263.x

${ }^{35}$ Baumeister RF, Bratslavsky E, Muraven M, et al. Ego depletion: Is the active self a limited resource? J Pers Soc Psychol 1998;74(5):1252-65. doi: 10.1037/0022-3514.74.5.1252

${ }^{36}$ de Ridder DTD, Lensvelt-Mulders G, Finkenauer C, et al. Taking stock of self-control: A meta-analysis of how trait selfcontrol relates to a wide range of behaviors. Pers Soc Psychol Rev 2012;16(1):76-99. doi: 10.1177/1088868311418749

${ }^{37}$ Verplanken B, Herabadi AG, Perry JA, et al. Consumer style and health: The role of impulsive buying in unhealthy eating. Psychol Health 2005;20(4):429-41. doi: 10.1080/08870440412331337084

${ }^{38}$ Wills TA, Isasi CR, Mendoza D, et al. Self-control constructs related to measures of dietary intake and physical activity in adolescents. J Adolesc Health 2007;41(6):551-8. doi: 10.1016/j.jadohealth.2007.06.013 
${ }^{39}$ Adriaanse MA, Kroese FM, Gillebaart M, et al. Effortless inhibition: Habit mediates the relation between self-control and unhealthy snack consumption. Front Psychol 2014;5(444):10-5. doi: 10.3389/fpsyg.2014.00444

40 Junger $M$, van Kampen $M$. Cognitive ability and self-control in relation to dietary habits, physical activity and bodyweight in adolescents. Int J Behav Nutr Phys Act 2010;7(22). doi: 10.1186/1479-5868-7-22

${ }^{41}$ McCarthy MB, Collins, AM, Flaherty SJ, et al. Healthy eating habit: A role for goals, identity, and self-control? Psychol Market 2017;34(8), 772-85. doi: 10.1002/mar.21021

${ }^{42}$ Serlachius A, Pulkki-Råback L, Juonala M, et al. Does high optimism protect against the inter-generational transmission of high BMI? The Cardiovascular Risk in Young Finns Study. J Psychosom Res 2017;100: 61-4. doi: 10.1016/j.jpsychores.2017.07.006

43 Tiger L. Optimism: The biology of hope. Simon and Schuster, New York, 1979.

${ }^{44}$ Kelloniemi H, Ek E, Laitinen J. Optimism, dietary habits, body mass index, and smoking among young Finnish adults. Appetite 2005;45(2):169-76. doi: 10.1016/j.appet.2005.05.001

${ }^{45}$ Renner B, Schwarzer R. Social-cognitive factors in health behavior change. In: Suls J, Wallston KA. (eds.) Social psychological foundations of health and illness. Blackwell Publishing, 2003; pp. 169-96.

${ }^{46}$ Kopp MS, Schwarzer R, Jerusalem M. Hungarian questionnaire in psychometric scales for cross cultural self-efficacy research. Zentrale Universitäts Druckerei der FU Berlin, 1993.

${ }^{47}$ Scheier MF, Carver CS. Optimism, coping, and health: Assessment and implications of generalized outcome expectancies. Health Psychol 1985;4:219-47. doi: 10.1037//0278-6133.4.3.219

${ }^{48}$ Bérdi M, Köteles F. Az optimizmus mérése: Az életszemlélet teszt átdolgozott változatának (LOT-R) pszichometriai jellemzői hazai mintán. Mentálhig Pszichoszom 2010;65(2):273-94. doi: 10.1556/MPSzle.65.2010.2.7

${ }^{49}$ Tangney JP, Baumeister RF, Boone AL. High self-control predicts good adjustment, less pathology, better grades, and interpersonal success. J Pers 2004;72(2):271-324. doi: 10.1111/j.0022-3506.2004.00263.x

${ }^{50}$ Shojaei, S, Farhadloo R, Aein A, Vahedian M. Effects of the Health Belief Model (HBM)-Based Educational Program on the nutritional knowledge and behaviors of CABG patients. J Tehran Heart Cent 2016; 11(4): 181-6.

${ }^{51}$ Pikó B, Gibbons FX. Behavioral and psychosocial influences of risk perception among Hungarian adolescents. International J Publ Health 2008;53:131-8.

52 Szabó K, Pikó B. Az étkezési magatartás összefüggése az ételválasztási motivációkkal és egyes személyiségbeli jellemzőkkel középiskolások körében. Egészségfejl 2017;58(2):5-16.

${ }^{53}$ Story M, Neumark-Sztainer D, French S. Individual and environmental influences on adolescent eating behaviors. J Am Diet Assoc 2002;102(3):S40-S51. doi: 10.1016/s0002-8223(02)90421-9

${ }^{54}$ Glanz K, Sallis JF, Saelens BE, Frank LD. Healthy nutrition environments: concepts and measures. Am J Health Prom 2005;19(5):330-3. doi: 10.4278/0890-1171-19.5.330 